\title{
KELAYAKAN KUALITAS AIR UNTUK KAWASAN BUDIDAYA Eucheuma cottoni BERDASARKAN ASPEK FISIKA, KIMIA DAN BIOLOGI DI KABUPATEN KEPULAUAN SELAYAR
}

\section{(Water Quality Fitness for Cultivation of Eucheuma cottoni based on Physics, Chemitstry and Biology Aspects In District Islands Selayar)}

\author{
Abdul Akib1*, Magdalena Litaay', Ambeng', Muhtadin Asnady' \\ 1. Program Studi Biologi, Fakultas Matematika dan Ilmu Pengetahuan Alam, Universitas \\ Hasanuddin, Makassar \\ e-mail : abdulakib24@yahoo.co.id
}

The research on the feasibility of water quality for cultivation area Eucheuma cottonii based on aspects of physics, chemistry and biology in the District of Selayar, on SeptemberNovember 2014 had been done. This study aims to determine the seaweed cultivation area based on the condition of physics, chemistry and biology parameters in the waters Selayar. Determination of a proposed seaweed cultivation area was conducted by using conformity criterias based on the results matrix scoring and weighting. The results showed a range of values: a) Physical parameters consist of: (1) the depth of $6.5 \mathrm{~m}$ to $11.5 \mathrm{~m}$, (2) brightness of $1.61 \mathrm{~m}$ to $6.51 \mathrm{~m}$, (3) water temperature $29^{\circ} \mathrm{C}-30.7{ }^{\circ} \mathrm{C}$, (4) salinity waters $28 \mathrm{ppt}-31.5 \mathrm{ppt},(5)$ water bottom material types include: mud, sand and coral, (6) the flow velocity of $0.02 \mathrm{~m} / \mathrm{s}$ $0.156 \mathrm{~m} / \mathrm{s}$, (7) payload suspended solids $16.097 \mathrm{mg} / \mathrm{l} 58.350 \mathrm{mg} / \mathrm{l}$. b) Chemical parameters consist of: (1) 3 dissolved oxygen ppt- $6.3 \mathrm{ppm}$, (2) pH 7,13- 7.66, (3) phosphate $0.211 \mathrm{mg} / \mathrm{l}$ $1.904 \mathrm{mg} / \mathrm{l}$, (4) nitrate 0,032- $\mathrm{mg} / \mathrm{l}-1.412 \mathrm{mg} / \mathrm{l}$. c) Biological parameters consist of: (1) the abundance of phytoplankton 20500 cells/l -46500 cells/l and (2) of chlorophyll-a $0.110 \mathrm{mg} / \mathrm{l}-$ $0.889 \mathrm{mg} / \mathrm{l}$. Scoring results show for the fifth station can be used for farming $E$. cottonii activities, namely in the village Bonelohe, Baruyya, Barugayya, Dodaia and Tongke-tongke.

Keywords: Aquaculture, Seaweed, Physics, Chemistry, Biology, Selayar

Telah dilakukan penelitian tentang kelayakan kualitas air untuk kawasan budidaya Eucheuma cottonii berdasarkan aspek fisika, kimia dan biologi di Kabupaten Kepulauan Selayar, pada bulan September - November 2014. Penelitian ini bertujuan mengetahui kawasan budidaya rumput laut berdasarkan kondisi fisika, kimia dan biologi di perairan Kepulauan Selayar. Penentuan lokasi budidaya rumput laut dilakukan dengan penyusunan matrik kesesuaian berdasarkan hasil skoring dan pembobotan. Hasil penelitian memperlihatkan kisaran nilai: a) Parameter fisika terdiri atas: (1) kedalaman sebesar 6,5 m- 11,5 m, (2) kecerahan $1,61 \mathrm{~m}-6,51 \mathrm{~m}$, (3) suhu perairan $29{ }^{\circ} \mathrm{C}-30,7 \stackrel{\circ}{\circ} \mathrm{C}$, (4) salinitas perairan $28 \mathrm{ppt}-$ $31,5 \mathrm{ppt}$, (5) material dasar perairan mempunyai jenis antara lain: lumpur, pasir dan karang, (6) kecepatan arus $0,02 \mathrm{~m} /$ det $-0,156 \mathrm{~m} / \mathrm{det}$, (7) muatan padatan tersuspensi $16,097 \mathrm{mg} / \mathrm{l}-58,350$ $\mathrm{mg} / \mathrm{l}$. b) Parameter kimia terdiri dari: (1) oksigen terlarut $3 \mathrm{ppt}-6,3 \mathrm{ppm}$, (2) pH 7,13- 7,66, (3) fosfat $0,211 \mathrm{mg} / \mathrm{l}-1,904 \mathrm{mg} / \mathrm{l}$, (4) nitrat 0,032- $\mathrm{mg} / \mathrm{l}-1,412 \mathrm{mg} / \mathrm{l}$. c) Parameter biologi terdiri atas: (1) kelimpahan fitoplankton $20500 \mathrm{sel} / \mathrm{l}-46500 \mathrm{sel} / \mathrm{l}$ dan (2) klorofil-a $0,110 \mathrm{mg} / \mathrm{l}-0,889 \mathrm{mg} / \mathrm{l}$. Hasil skoring menunjukkan untuk kelima stasiun dapat dilakukan kegiatan budidaya $E$. cottonii yaitu pada desa Bonelohe, Baruyya, Barugayya, Dodaia dan Tongke-tongke.

Kata kunci : Budidaya, Rumput Laut, Fisika, Kimia, Biologi, Selayar 


\section{PENDAHULUAN}

Secara Geografis, Kabupaten Kepulauan Selayar Propinsi Sulawesi Selatan terletak di antara $5^{\circ} 42^{\prime}-7^{\circ}-35^{\prime}$ Lintang Selatan dan $120^{\circ} 15^{\prime}$ - $122^{\circ} 30^{\prime}$ Bujur Timur. Luas keselurahan Wilayah mencakup 10.503,69 $\mathrm{Km}^{2}$ dimana luas daratan 1.357,03 $\mathrm{Km}^{2}(12,92 \%)$ dan luas laut 9.146,66 $\mathrm{Km}^{2} \quad(87,08 \%)$. Wilayah Kabupaten Kepulauan Selayar terdiri dari 123 (seratus dua puluh tiga) buah gugus pulau besar dan pulau kecil. Dengan keadaan geografis inilah memberikan peluang besar bagi kepulauan selayar dalam usaha budidaya rumput laut (Coremap, 2006).

Kekayaan potensi sumberdaya pesisir dan laut Kabupaten Selayar dengan 123 pulau merupakan potensi untuk pengembangan budidaya laut (Coremap, 2006).

\begin{tabular}{lrr}
\multicolumn{1}{c}{ Salah } & satu & pengembangan \\
kegiatan & ekonomi yang & sedang \\
dijalankan & pemerintah & ialah
\end{tabular} pengembangan budidaya rumput laut. Melalui program ini diharapkan dapat merangsang terjadinya pertumbuhan ekonomi wilayah akibat meningkatnya pendapatan masyarakat setempat (Departemen Kelautan dan Perikanan, 2001).

Eucheuma cottonii adalah salah satu jenis rumput laut yang banyak dimanfaatkan untuk kegiatan budidaya di berbagai negara Asia Pasifik termasuk Indonesia. Data statistik Dikjen Perikanan Budidaya KKP tahun 2001-2010 menunjukkan bahwa produksi rumput laut Indonesia meningkat dari tahun 2001 yang menghasilkan 25.000 ton menjadi 55.000 ton pada tahun 2004 dan pada tahun 2010 menghasilkan 2,96 juta ton. Dari data ini perkembangan budidaya rumput laut akan terus berkembang. Peningkatan produksi harus didukung degan sistem distribusi dan pemasaran yang baik sehingga terjadi distribusi nilai tambah yang baik. Euchema menghasilkan karaginan jenis kappa. Karagenan yang dihasilkan oleh Euchema dimanfaatkan pada industri makanan, kosmetik, obat-obatan, tekstil, cat dan sebagai materi dasar dari aromatic diffuser (Ghufran, 2010).

Pemilihan lokasi yang tepat merupakan faktor yang penting dalam menentukan kelayakan usaha budidaya rumput laut. Faktor utama keberhasilan kegiatan budidaya rumput laut adalah pemilihan lokasi yang tepat. Di antara faktor lingkungan tersebut adalah ketersediaan cahaya, suhu, salinitas, arus dan ketersediaan nutrien (Lobban and Harrison, 1997). Oleh karena itu faktor fisika, kimia dan biologi dari suatu perairan menjadi salah satu penentu keberhasilan budidaya rumput laut. Parameter lingkungan yang menjadi penentu lokasi yang tepat untuk budidaya rumput laut adalah kondisi lingkungan fisik yang meliputi kedalaman, kecerahan, kecepatan arus, Muatan Padatan Tersuspensi (MPT) atau Total Suspended Solid (TSS), dan lingkungan kimia yang meliputi salinitas, $\mathrm{pH}$, oksigen terlarut, nitrat dan fosfat, serta aspek biologi yang meliputi kelimpahan fitoplankton dan klorofil-a.

Berdasarkan studi referensi dan hasil penelitian yang ada, maka peneliti tertarik untuk melakukan penelitian tentang uji kelayakan kualitas air untuk kawasan budidaya E. cottonii di Kepulauan Selayar berdasarkan aspek fisika, kimia dan biologi.

\section{METODE PENELITIAN}

Metode penelitian yang dilakukan adalah pengumpulan data primer yang dilakukan dengan pengukuran langsung parameter fisika, kimia dan biologi di lapangan. Analisis kualitas air di lakukan di Laboratorium Oseanografi Kimia Jurusan IImu Kelautan dan Perikanan serta analisis data dilakukan di Laboratorium IImu Lingkungan dan Kelautan FMIPA Universitas Hasanuddin.

Lokasi penelitian meliputi perairan Kabupaten Selayar yang terletak di laut 




Gambar 1. Peta lokasi titik pengambilan sampel kualitas air di Kabupaten Kepulauan Selayar (Modifikasi dari Coremap, 2006).

Flores yang berada pada titik koordinat $5^{\circ} 42^{\prime}-7^{\circ} 35^{\prime}$ LS dan $120^{\circ} 15^{\prime}-122^{\circ} 30^{\prime}$ BT dan titik stasiun digambarkan pada peta wilayah pengambilan sampel E. cottonii (Gambar 1).

Alat-alat yang digunakan dalam penelitian ini terbagi atas dua : 1) alat lapangan yang digunakan adalah perahu motor, Global Positioning System (GPS), layang-layang arus, stopwatch, sedimen Grab, secchi disk, Water Quality Checker (WQC), ember 10L, plankton net 25, pipet tetes, $\mathrm{pH}$ meter, botol sampel, cool box, kompas, kamera, alat tulis menulis, 2) alat yang digunakan di laboratorium adalah Spektrofotometer DREL 2800, mikroskop Sargent-Welch, kertas saring Whatman No. 42, tabung reaksi, rak tabung, corong, erlemeyer, pipet, labu ukur, karet bulp.

Bahan-bahan yang digunakan antara lain untuk analisis nitrat yaitu: indicator brucine, asam sulfat pekat; $\mathrm{H}_{2} \mathrm{SO}_{4}$, natrium nitrat; $\mathrm{NaNO}_{3}$. Untuk analisis fosfat bahan yang digunakan yaitu ammonium molybdate; $\left(\mathrm{NH}_{4}\right)$ $8 \mathrm{MO} 7024.4 \mathrm{H}_{2} \mathrm{O}$, asam borat $1 \%$; $\mathrm{H}_{3} \mathrm{BO}_{3}$, asam sulfat $2,5 \mathrm{M} ; \mathrm{H}_{2} \mathrm{SO}_{4}$, asam ascorbic 1\%, kertas saring
Whatman no.42. Adapun bahan lain yang digunakan yaitu lugol $100 \mathrm{ml}$, sampel air laut, penyaring millipora (kertas saring Whatman ukuran pori $0,45 \mu \mathrm{m}$, tissue \& aquades.

Penentuan titik pengambilan sampel terbagi atas 5 stasiun yang sebelumnya dilakukan observasi lokasi untuk mendapatkan gambaran umum mengenai lokasi-lokasi yang nantinya akan dijadikan sebagai titik pengambilan sampel di Pulau Selayar. Posisi pengambilan dicatat dengan bantuan Global Positioning System (GPS).

Pengambilan sampel di tiap stasiun dilakukan sebanyak 3 kali. Adapun stasiun pengambilan sampel tersebut yaitu:

$>$ Stasiun I terletak di desa Bonelohe yang berada di sebelah utara pulau Selayar.

> Stasiun II terletak di desa Baruia Kecamatan Batangmata.

> Stasiun III berada di desa Barugaia Kecamatan Bontoharu.

$>$ Stasiun IV berada di desa Dodaiya Kecamatan Bontosikuyu.

$>$ Stasiun $\mathrm{V}$ berada di desa Tongketongke Kecamatan Bontosikuyu. Tongke-tongke Kecamatan Bontosikuyu.

Pengambilan sampel parameter fisika, kimia dan biologi di perairan dilakukan pada pukul 08.00 Wita sampai pukul 17.00 Wita. Sampel yang didapat dilakukan pengukuran secara in situ, dan sampel yang perlu dianalisis lebih lanjut dibawa ke laboratorium Oseanografi Kimia, Jurusan IImu Kelautan Fakultas IImu Kelautan dan Perikanan, Universitas Hasanuddin.

Parameter kualitas perairan yang diukur terbagi atas 3 yaitu:

Parameter Fisika, variabel yang diukur meliputi:

- Kedalaman perairan. Pengukuran kedalaman dilakukan dengan menggunakan tali tambang yang ada pada sedimen grab yang 
sudah diberi tanda untuk tiap meternya.

- Kecerahan air. Pengambilan data kecerahan air dilakukan dengan menggunakan alat sechii disc, pada setiap titik sampling.

- Suhu perairan. Pengukuran dengan menggunakan water quality checker tipe Horiba U10A di setiap titik sampling dengan skala pengukuran $1^{\circ} \mathrm{C}$.

- Salinitas, salinitas diukur menggunakan water quality checker tipe Horiba U10A.

- Kecepatan arus. Informasi kecepatan arus diperlukan untuk mengetahui arah dan besarnya massa air yang mengalir serta mengetahui penyebaran limbah, sedimen atau bahan lainnya. Aliran masa air diukur pada suatu titik yang tetap. Layang-layang arus merupakan alat yang digunakan untuk mengukur arus, alat ini merupakan modifikasi Lembaga IImu dan Pengetahuan (LIPI) Ambon.

- Material dasar perairan. Pengambilan sampel dilakukan dengan menggunakan alat Egman grab sample dan kemudian dianalisis di laboratorium.

- Muatan pada tersuspensi (MPT). Metode yang digunakan dalam pengukuran muatan padatan tersuspensi adalah gravimetrik dengan alat penyaring millipora (Badan Pengendalian Dampak Lingkungan, 1996). Setelah prosedur kerja berakhir selanjutnya dilakukan perhitungan dengan menggunakan rumus (APHA, AWWA, WPCF,1989) dibawah ini:

$$
\text { MPT }=\frac{(a-b) \mathrm{X} 1000}{c} \mathrm{mg} / \text { liter }
$$

Keterangan :

$$
\begin{aligned}
& \mathrm{a}=\text { Berat kertas saring dan } \\
& \text { residu setelah pemanasan } \\
& \text { (mg) } \\
& \mathrm{b}=\text { Berat kering filter }(\mathrm{mg})
\end{aligned}
$$

$$
\mathrm{C}=\text { Volume sampel air laut }(\mathrm{ml})
$$

Parameter Kimia, variabel yang diukur meliputi :

- $\mathrm{pH}$, pengukuran $\mathrm{pH}$ dengan menggunakan water quality checker tipe Horiba U10A

- Oksigen terlarut, pengukuran oksigen terlarut pada tiap titik sampling dengan menggunakan water quality checker tipe Horiba U10A

- Fosfat, pengukuran fosfat dilakukan menurut petunjuk Boyd (1981)

- Nitrat, analisis nitrat dilakukan menurut petunjuk Suin (1999).

Parameter Biologi, variabel yang diukur pada parameter biologi yaitu:

- Kelimpahan fitoplankton, pengambilan sampel dilakukan secara pasif. Jumlah plankton dihitung dengan menggunakan petunjuk APHA (1976).

$$
\mathrm{N}=\mathrm{T} / \mathrm{L} \times \mathrm{P} / \mathrm{p} \times \mathrm{V} / \mathrm{v} \times 1 / \mathrm{w}
$$

Keterangan :

$\mathrm{N}=$ Jumlah plankton (individu /)

$\mathrm{P}=$ Jumlah plankton tercacah

$\mathrm{P}=$ Jumlah lapang pandang diamati

$\mathrm{V}=$ Volume dibawah gelas penutup $(m l)$

$\mathrm{T}=$ Luas gelas penutup $\left(\mathrm{mm}^{2}\right)$

$\mathrm{L}=$ Luas lapang pandang $\left(\mathrm{mm}^{2}\right)$

$\mathrm{V}=$ Volume sampel yang diamati $(50 \mathrm{ml})$

$\mathrm{W}=$ Volume air yang disaring $(10 \mathrm{~L})$

Klorofil-a, pengukuran klorofil-a dilakukan menurut petunjuk Rosen (1990)pengukuran menggunakan konsentasi klorofil-a dengan rumus:

Klorofil-a $\mu \mathrm{g} / \mathrm{ml}=11,85 \times$ A664. 1,54 x A647-0,08 x A630

Pengolahan data dilakukan dengan menghitung kecepatan arus yang diukur dengan persamaan (Kreyzing, 1993 dalam Rasyid, 2005):

$$
\mathrm{V}=\mathrm{s} / \mathrm{t}
$$


Keterangan:

$$
\begin{aligned}
& \mathrm{V}=\text { Kecepatan arus (m/detik) } \\
& \mathrm{s}=\operatorname{Jarak}(\mathrm{m}) \\
& \mathrm{t}=\text { Waktu (detik) }
\end{aligned}
$$

Untuk analisis kesesuaian perairan bagi budidaya rumput laut maka dibuat matrik kesesuaian perairan untuk parameter fisika, kimia dan biologi. Penyusunan matrik kesesuaian perairan merupakan dasar dari analisis keruangan melalui skoring dan faktor pembobot. Hasil skoring dan pembobotan dievaluasi sehingga didapatkan kategori kesesuaian yang menggambarkan tingkat kecocokan dari suatu bidang untuk penggunaan tertentu. Tingkat kesesuaian dibagi atas empat kriteria kategori yang meliputi (Bakosurtanal, 1996) :

$>$ Kategori S1; Sangat sesuai (Highly Suitable). Daerah ini tidak mempunyai pembatas yang serius untuk menerapkan perlakuan yang diberikan.

$>$ Kategori S2; Cukup sesuai (Moderately Suitable), Daerah ini mempunyai pembataspembatas yang agak serius untuk mempertahankan tingkat perlakukan yang harus diterapkan. Pembatas ini akan meningkatkan masukan atau tingkat perlakuan yang diperlukan.

$>$ Kategori S3; Sesuai marginal (Marginally Suitable). Daerah ini mempunyai pembataspembatas yang serius untuk mempertahankan tingkat perlakuan yang harus diterapkan. Pembatas akan lebih meningkatkan masukan atau tingkatan perlakuan yang diperlukan.

> Kategori N; Tidak sesuai (Not Suitable), Daerah ini mempunyai pembatas permanen, sehingga mencegah segala kemungkinan perlakuan pada daerah tersebut.

\section{HASIL DAN PEMBAHASAN}

\section{Kedalaman Perairan}

Hasil pengukuran kedalaman perairan pada titik sampling di zona pemanfaatan budidaya rumput laut Kabupaten Kepulauan Selayar berkisar antara $6,5 \mathrm{~m}$ sampai $11,5 \mathrm{~m}$, dengan nilai rata-rata yang bervariasi terdiri dari $7,67 \mathrm{~m}$ sampai $9,67 \mathrm{~m}$. Nilai kedalaman tertinggi berdasarkan nilai rata-rata terdapat pada stasiun III yaitu desa Barugayya, sedangkan nilai terendah berada pada stasiun I yaitu desa Bonelohe.

Berdasarkan nilai yang ada pada table matrik kesesuaian untuk nilai kedalaman menunjukkan nilaiyang sesuai untuk dilakukannya budidaya rumput laut.

\section{Kecerahan Air}

Kecerahan perairan di zona pemanfaatan budidaya rumput laut di pulau Selayar berkisar antara 1,61 m hingga $6,51 \mathrm{~m}$ dengan rata-rata untuk semua stasiun berkisar antara 2,04 sampai dengan 6,09 m. Sebaran kecerahan tertinggi berada pada stasiun III yaitu desa Dodaia, sedangkan nilai kecerahan terendah berada pada stasiun I yaitu pada desa Bonelohe. Adanya perbedaan kecerahan di perairan Selayar pada setiap lokasi pengambilan sampel berhubungan dengan kedalaman lokasi, substansi sedimen, kecepatan arus dan waktu dilakukannya pengamatan. Hutabarat (2000) mengatakan bahwa, cahaya akan semakin berkurang intensitasnya seiring dengan makin besar kedalaman. Pendugaan lain adalah adanya perbedaan waktu pengamatan yang dilakukan. Effendi (2003) mengatakan bahwa pemantulan cahaya mempunyai intensitas yang bervariasi menurut sudut datang cahaya. 
Tabel 1. Skoring Hasil Evaluasi untuk Kesesuaian Perairan Budidaya Eucheuma cottonii.

\begin{tabular}{|c|c|c|c|c|c|}
\hline \multirow{2}{*}{ Variabel } & Stasiun & Stasiun & Stasiun & Stasiun & Stasiun \\
\hline & $\mathrm{I}$ & II & III & IV & $\mathrm{V}$ \\
\hline Kedalaman (m) & 15 & 15 & 12,9 & 12,9 & 12,9 \\
\hline Kecerahan (m) & 9 & 12,9 & 9 & 15 & 15 \\
\hline Arus (cm/det) & 3 & 1,6 & 1,6 & 2,3 & 1,6 \\
\hline Nitrat (mg/l) & 10,8 & 9 & 9 & 9 & 9 \\
\hline Fosfat (mg/l) & 12,9 & 12,9 & 12,9 & 10,8 & 15 \\
\hline $\mathrm{MPT}(\mathrm{mg} / \mathrm{l})$ & 6 & 6 & 2 & 4,3 & 8,6 \\
\hline Salinitas Perairan (ppt) & 10 & 10 & 10 & 10 & 10 \\
\hline Suhu $\left({ }^{\circ} \mathrm{C}\right)$ & 8,6 & 10 & 8,6 & 8,6 & 7,2 \\
\hline Material Perairan & 5 & 5 & 5 & 5 & 2,3 \\
\hline Kelimpahan Fitoplankton (sel/l) & 5 & 5 & 5 & 5 & 5 \\
\hline Klorofil-a (mg/l) & 2,3 & 2,3 & 2,3 & 1,6 & 3 \\
\hline Oksigen Terlarut (mg/l) & 1,6 & 1 & 2,3 & 3 & 3,6 \\
\hline $\mathrm{pH}$ & 5 & 5 & 5 & 5 & 5 \\
\hline Jumlah & 89,2 & 95,7 & 85,5 & 92,5 & 98,2 \\
\hline Nilai (Skor) & $69 \%$ & $73 \%$ & $66 \%$ & $71 \%$ & $76 \%$ \\
\hline Keterangan & $\begin{array}{l}\text { Cukup } \\
\text { Sesuai }\end{array}$ & $\begin{array}{l}\text { Cukup } \\
\text { Sesuai }\end{array}$ & $\begin{array}{l}\text { Cukup } \\
\text { Sesuai }\end{array}$ & $\begin{array}{l}\text { Cukup } \\
\text { Sesuai }\end{array}$ & Sesuai \\
\hline
\end{tabular}

Berdasarkan nilai rata-rata pada kecerahan perairan pada zona pemanfaatan umum Pulau Selayar memperlihatkan kisaran nilai yang masih dianjurkan, terutama pada stasiun II, stasiun IV dan stasiun V sementara untuk stasiun I dan stasiun III dapat dilakukan budidaya rumput laut karena nilai yang dimiliki masuk dalam kategori sedang berdasarkan matriks kesesuaian untuk budidaya rumput laut.

\section{Suhu Perairan}

Suhu perairan pada titik pengambilan sampel untuk budidaya rumput laut di pulau Selayar diperoleh dengan menggunakan alat WQC
(Water Quality Checker) yang berkisar antara $2^{\circ} \mathrm{C}$ sampai $30,7^{\circ} \mathrm{C}$ dengan nilai rata-rata yang bervariasi untuk kelima stasiun yang terdiri dari $29,33^{\circ} \mathrm{C}$ sampai $30,3^{\circ} \mathrm{C}$. Suhu rendah didapat pada stasiun I, stasiun II, stasiun III dan stasiun IV, sementara suhu tertinggi diperoleh di stasiun $\mathrm{V}$ di perairan desa Tongke-tongke. Perbedaan tersebut karena adanya selisih waktu pengukuran in situ terhadap variabel ini. Effendi (2003) mengatakan bahwa suhu perairan berhubungan dengan kemampuan pemanasan oleh sinar matahari, waktu dalam hari dan lokasi. Hal ini didukung oleh Basmi (1999) dan Hutabarat (2000) yang mengatakan bahwa perairan lebih lambat menyerap 
panas tetapi akan menyimpan panas lebih lama dibandingkan dengan daratan. Secara umum rata-rata suhu di perairan Selayar untuk budidaya E. cottonii memperlihatkan nilai yang mendukung untuk dilakukannya kegiatan budidaya rumput laut.

\section{Kecepatan Arus}

Pengukuran kecepatan arus dengan menggunakan alat layanglayang arus dimana hasil pengukuran memperlihatkan kecepatan yang bervariasi antara $0,02 \mathrm{~m} /$ det sampai $0,156 \mathrm{~m} /$ det dengan nilai rata-rata untuk kelima stasiun berkisar antara $0,064 \mathrm{~m} / \mathrm{det}$ sampai dengan $0,113 \mathrm{~m} /$ det. Kecepatan arus terendah berada pada stasiun 4.3 dan stasiun 5.3 sedangkan kecepatan arus tertinggi berada pada stasiun 4.2. Perbedaan kecepatan arus disebabkan oleh letak lokasi. Adanya terumbu karang yang merupakan salah satu penyebab arus menjadi lemah, karena arus laut yang datang terhambat oleh barier yang dibentuk secara alami oleh terumbu karang. Pada saat yang lain adanya turbulensi dan perairan yang cukup terbuka merupakan pendugaan lain terjadi perbedaan kuat arus. Wibisono (2005) mengatakan bahwa setiap proses aktivitas pasang maupun surut menimbulkan arus. Hal ini disebabkan penelitian yang dilakukan dalam jangka waktu yang pendek dan hanya sekali saja. Sehingga disimpulkan bahwa arus yang terjadi merupakan arus lokal akibat pasangsurut. Kecepatan arus berperan penting dalam perairan, misalnya: pencampuran masa air, pengangkutan unsur hara, transportasi oksigen.

\section{Muatan Padatan Tersuspensi}

Hasil pengukuran terhadap variabel muatan padatan tersuspensi di perairan Selayar sebagai zona pemanfaatan budidaya $E$. cottonii memperlihatkan nilai pengukuran yang berkisar antara 16,097 mg/l sampai $58,350 \mathrm{mg} / \mathrm{l}$ dengan nilai ratarata berkisar antara $30,961 \mathrm{mg} / \mathrm{l}$ sampai $37,537 \mathrm{mg} / \mathrm{l}$. Berdasarkan hasil pengujian didalam laboratorium nilai MPT terendah berda pada stasiun 3.3 atau pada desa Barugayya, sementara muatan padatan tersuspensi yang paling tinggi didapatkan pada stasiun 1.3 atau pada desa Bonelohe. Perbedaan nilai padatan tersuspensi pada tiaptiap lokasi pengambilan sampel disebabkan oleh komposisi material dasar perairan dan pergerakan massa air terhadap substrat.

\section{Material Dasar Perairan}

Hasil penelitian terhadap material dasar di perairan Selayar memperlihatkan adanya perbedaan jenis material dasar perairan pada beberapa lokasi. Perbedaan tersebut dapat dibagi menjadi dua jenis, yaitu: (a) jenis koral dan campuran koral pasir yang berada di depan mulut teluk, (b) jenis lumpur tercampur pasir.

Hasil penelitian menunjukan bahwa material dasar perairan pada zona budidaya rumput laut di perairan Selayar masih berada dalam kisaran yang dianjurkan untuk dilakukannya kegiatan budidaya rumput laut, terutama pada empat lokasi yang berada pada desa Bonelohe, Baruyya, Barugaiya dan Dodaia dengan komposisi pasir berkarang dan karang. Sementara pada desa Tongke-tongke memiliki substrat berlumpur sehingga diperlukan perhatian khusus untuk menjaga pertumbuhan rumput laut.

\section{Salinitas Perairan}

Nilai salinitas yang didapatkan pada lokasi pemanfaatan budidaya rumput laut berkisar antara $28 \mathrm{ppt}$ sampai 31,5 ppt dengan nilai rata-rata untuk kelima stasiun berkisar antara 29,33 ppt sampai 30,833 ppt. Kisaran nilai salinitas terendah berada pada desa Baruya yaitu stasiun 2.1 sedangkan nilai salinitas tertinggi terdapat pada desa Tongke-tongke yaitu pada stasiun 5.3. Adanya perbedaan kisaran salinitas terutama pada perairan Selayar disebabkan 
karenaa danya berbagai faktor seperti sirkulasi air, penguapan, curah hujan dan aliran sungai.

Nilai salinitas yang diperoleh pada perairan Selayar menunjukan angka yang sesuai untuk dilakukan budidaya rumput laut tanpa harus diberikan fakor pembatas.

\section{pH}

Pengukuran nilai $\mathrm{pH}$ di perairan Selayar dengan menggunakan Water Qualty Checker (WQC) memperlihatkan kisaran nilai antara 7.13 sampai 7.66 , dengan nilai ratarata terendah yaitu 7,21 smentra nilai rata-rata tertingi adalah 7,43 Nilai $\mathrm{pH}$ terendah terdapat pada desa Baruiya dan Tongke-togke sementara nilai tertinggi berada pada desa Bonelohe yaitu pada stasiun 1.1. Perbedaan nilai $\mathrm{pH}$ dalam perairan disebabkan oleh adanya perbedaan waktu pengukuran. Perubahan konsentrasi $\mathrm{pH}$ dalam perairan mempunyai siklus harian. Siklus ini merupakan fungsi dari karbondioksida. Effendi (2003) mengatakan bahwa jika perairan mengandung kabondioksida bebas dan ion karbonat maka $\mathrm{pH}$ cenderung asam, dan $\mathrm{pH}$ akan kembali meningkat jika $\mathrm{CO}_{2}$ dan $\mathrm{HCO}_{3}$ mulai berkurang.

Hasil penelitian memperlihatkan adanya perbedaan $\mathrm{pH}$ pada tiap lokasi pengambilan sampel, tetapi secara keseluruhan nilai rata-rata $\mathrm{pH}$ di perairan zona pemanfaatan budidaya rumput laut berada dalam kisaran yang mendukung untuk dilakukannya budidaya rumput laut.

\section{Oksigen Terlarut}

Hasil pengukuran secara in situ terhadap oksigen terlarut di perairan zona pemanfaatan umum pulau Selayar memperlihatkan kisaran nilai antara 3ppm dan nilai tertinggi adalah 6,3 ppm dengan nilai rata-rata untuk kelima stasiun berkisar antara 3,25 ppm sampai 4,63 ppm. Kandungan oksigen terlarut terendah pada desa Bonelohe dan nilai tertinggi berada pada desa Dodaiya dengan. Berbedanya kandungan oksigen terlarut karena adanya pergerakan dan percampuran massa air serta siklus harian variabel ini.

Brotowidjoyo et al. (1995) mengatakan bahwa pada kondisi perairan terbuka, oksigen berada pada kondisi alami sehingga jarang dijumpai pada kondisi perairan terbuka yang miskin oksigen.

\section{Fosfat}

Kandungan fosfat dalam perairan Selayar mempunyai nilai yang bervariasi antara 0,096 $\mathrm{mg} / \mathrm{l}$ sampai $1,904 \mathrm{mg} / \mathrm{l}$, dengan nilai rata-rata antara $0,218 \mathrm{mg} / \mathrm{l}$ hinga $0,923 \mathrm{mg} / \mathrm{l}$. Kandungan fosfat terendah terdapat pada desa Tongke-tongke yaitu pada stasiun 5.3 dan nilai fosfat tertinggi berada pada desa Dodaia yaitu pada stasiun 4.2. Perbedaan tersebut disebabkan oleh waktu dan daerah yang diteliti. Sedangkan perbedaan kandungan fosfat diduga disebabkan oleh adanya bahan organik berupa limbah domestik (detergen), limbah pertanian atau pengikisan batuan fosforoleh aliran air. Hampir sepanjang jalur dari pelabuhan Pamatata sampai desa Tongke-tongke merupakan daerah pemukiman peduduk dan ini memungkinkan masuknya limbah domestik atau pertanian (overfertilisasi). Pada struktur geologi penyusun pantai, juga terlihat ada perbedaan antara bagian utara dan selatan teluk dan ini memungkinkan terjadi pengikisan batuan. Menurut Effendi (2003) dan Supriharyono (2001), sebagian besar fosfat berasal dari masukan bahan organik melalui darat berupa limbah industri maupun domestik (detergen). Ditambahkan oleh Brotowidjoyo, et al. (1995) dan Hutabarat (2000) bahwa sumber fosfat di perairan juga berasal dari proses pengikisan batuan di pantai.

Kandungan fosfat di perairan Selayar memperlihatkan kisaran yang mendukung kegiatan budidaya. Fosfat 
sendiri dalam perairan berperan sebagai nutrien. Akan tetapi tingginya kandungan fosfat di perairan dapat berdampak pada peledakan plankton.

\section{Nitrat}

Hasil pengukuran terhadap variabel nitrat memperlihatkan nilai yang bervariasi antara $0.032 \mathrm{mg} / \mathrm{l}$ sampai $1,412 \mathrm{mg} / \mathrm{l}$ dengan nilai ratarata sebesar 0,091 $\mathrm{mg} / \mathrm{l}$ sampai dengan $0,53 \mathrm{mg} / \mathrm{l})$. Nitrat terendah terdapat pada desa Barugayya yaitu stasiun 3.3dan nilai nirat tertinggi terdapat pada desa Bonelohe dengan titik pengambilan sampel berada pada stasiun 1.1. Perbedaan kandungan nitrat pada beberapa lokasi disebakan oleh tingginya nitrat didasar perairan. Hutabarat (2000) bahwa konsentrasi nitrat akan semakin besar dengan bertambahnya kedalaman.

Perbedan nilai rata-rata pada parameter nitra disebabkan karena adanya pemukiman penduduk yang memungkinkan masuknya nitrat ke dalam perairan. Effendi (2003) berpendapat bahwa kadar nitrat dalam perairan banyak dipengaruhi oleh pencemaran antropogenik yang berasal dari aktifitas manusia maupun tinja hewan. Jadi berdasarkan nilai rata-rata kandungan nitrat di peraiaran Selayar yang diperoleh, maka dapat dilakukan budidaya rumput untuk semua stasiun.

\section{Klorofil-a}

Hasil pengukuran terhadap variabel klorofil-a memperlihatkan nilai yang bervariasi antara $0,110 \mathrm{mg} / \mathrm{l}$ sampai $0,889 \mathrm{mg} / \mathrm{l}$ dengan nilai ratarata $0,288 \mathrm{mg} / \mathrm{l}$ hingga $0,56 \mathrm{mg} / \mathrm{l}$. Konsentrasi klorofil tertinggi terdapat pada desa Bonelohe dengan yaitu pada stasiun 1.1 dan nilai terendah terdapat pada desa Dodaiya yaitu pada stasiun 4.1.

Perbedaan nilai klorofil-a yang terdapat di perairan Selayar disebabkan oleh keberadaan fitoplankton, baik kelimpahannya maupun komposisi jenis terhadap pigmen yang dikandungnya. Nontji (2005) berpendapat bahwa klorofil-a berbeda berdasarkan lokasi dan jumlah plankton. Pendapat ini didukung oleh Yusuf, et al. (1995) yang mengatakan bahwa konsentrasi klorofil-a umumnya berhubungan dengan kelimpahan fitoplankton, khususnya bagi fitoplankton yang masih dalam keadaan hidup.

Hasil analisis memperlihatkan kandungan klorofil-a mempunyai kisaran yang tidak mendukung kegiatan budidaya rumput laut di Pulau Selayar.

\section{Kelimpahan Fitoplankton}

Hasil pengukuran terhadap kelimpahan fitoplankton adalah 20500 sel/l sampai 46500 sel/l dengan ratarata 28333 sel// sampai dengan 31670 . Kelimpahan fitoplankton terendah terdapat pada desa Barugayya yaitu pada stasiun 3.2 dan nilai kelimpahan fitoplankton tertinggi berada pada Bonelohe yaitu pada stasiun 1.1.

Secara umum kelimpahan fitoplankton di perairan Selayar berada pada kisaran yang mendukung kegaiatan budidaya rumput laut dilihat berdasarkan matrik kesesuaian.

\section{Penentuan Lokasi Kesesuaian Budidaya Laut}

Penentuan daerah kesesuaian budidaya laut mengacu pada matrik kesesuaian perairan yang disusun berdasarkan variabel primer, variabel sekunder dan variabel tersier. Ketiga variabel penyusun matrik kesesuaian tersebut merupakan variabel syarat yang terdiri dari komponen variabelvariabel dalam parameter físika, kimia dan biologi.

\section{Lokasi Pengembangan bagi Budidaya Rumput Laut (Seaweed) \\ Hasil evaluasi terhadap nilai} tersebut dengan mempergunakan kriteria pada Tabel 1 memperlihatkan perairan pulau Selayar berada pada kategori cukup sesuai (S3) untuk dilakukannya budidaya rumput laut. Variabel primer merupakan 
variabel yang perlu mendapat perhatian dalam usaha budidaya, dimana variable tersebut terdiri dari nitrat, fosfat, kedalaman, kecerahan perairan dan kecepatan arus. Fosfat merupakan unsur yang berperan dalam mendukung pertumbuhan dan perkembangan budidaya dalam pembentukan protein maupun aktivitas metabolisme. Pertumbuhan dapat tercapai dengan baik jika variabel ini tercukupi. Supriharyono (2001); Boyd (1990); Duty (2000) dan Hutabarat (2000) mengatakan bahwa fosfat merupakan unsur hara dalam perairan yang esensial untuk pertumbuhan E. cottonii. Walaupun unsur ini sangat penting bagi pertumbuhan $E$. cottonii, tetapi pada kondisi berlebihan akan menyebabkan peledakan mikroalga lainnya.

Muatan padatan tersuspensi di perairan Selayar merupakan variabel sekunder dalam penentuan lokasi kultivan ini. Padatan tersuspensi umumnya berpengaruh terhadap penetrasi cahaya kedalam kolom air. Kondisi ini menyebabkan aktivitas fotosintesis makro alga dapat terhambat. Walaupun termasuk dalam kategori cukup sesuai, tetapi variabel tersebut relatif tinggi dan dianggap sangat sulit diberikan masukan terhadap perubahannya.

Berdasarkan skoring yang telah dilakukan dengan menggunakan tabel yang ada pada Tabel 1. Maka dapat disimpulkan sebagai berikut:

\section{Stasiun I}

Stasiun I yang berada pada desa Bonelohe memperlihatkan nilai skor hasil evaluasi parameter fisika, kimia dan biologi menunjukkan kriteria cukup sesuai (S3) untuk lokasi budidaya rumput laut (Tabel 1). Hal ini dikarenakan hasil analisis data tiap komponen parameter fisika, kimia dan biologi berada pada kisaran yang sedang untuk pertumbuhan dan perkembangan budidaya rumput laut.

\section{Stasiun II}

Nilai skor hasil evaluasi parameter fisika, kimia dan biologi untuk stasiun II menunjukkan kriteria cukup sesuai (S3) untuk lokasi budidaya rumput laut E. cottonii (Tabel 1). Hal ini dikarenakan terdapat beberapa parameter seperti kecerahan, Oksigen terlarut, MPT, dan klorofil-a yang menunjukkan nilai sedang. Beberapa faktor di atas tidak menjadi faktor pembatas untuk dilakukannya budidaya rumput laut karena tiga dari empat faktor-faktor tersebut termasuk dalam kriteria tersier yang berarti tidak memberi dampak negativ jika dilakukan budidaya. Sementara kecerahan tergolong dalam komponen primer yang memerlukan perhatian serius namun karena nilai kecerahan yang ditampilkan pada stasiun II berada dalam kisaran cukup sesuai sehingga tidak menjadi penghalang untuk menjalankan usaha budidaya rumput laut.

\section{Stasiun III}

Nilai skor hasil evaluasi parameter fisika, kimia dan biologi untuk stasiun ini menunjukkan kriteria cukup sesuai (S3) untuk dijadikan sebagai lokasi budidaya rumput laut $E$. cottonii (Tabel 1). Beberapa faktor yang menyebabkan stasiun ini masuk dalam kategori cukup sesuai yaitu adanya beberapa parameter yang kurang baik seperti Oksigen terlarut dan klorofil-a yang memperlihatkan nilai analisis laboratorium yang kurang mendukung. Namun kedua parameter ini bukanlah menjadi parameter utama dalam penilaian untuk dilakukan budidaya karena tergolong dalam parameter tersier, namun tatap harus diperhatikan untuk menghindari kerusakan yang dapat terjadi pada budidaya rumput laut.

\section{Stasiun IV}

Nilai skor hasil evaluasi parameter fisika, kimia dan biologi untuk stasiun IV berada pada kisaran kriteria cukup sesuai (S3) untuk lokasi budidaya rumput laut $E$. cottonii (Tabel 1). Hal ini 
dikarenakan kecepatan arus berada pada kondisi kurang baik sehingga memerlukan perhatian khusus ketika dilakukan budidaya untuk menghindari terjadinya kerusakan pada rumput laut akibat arus yang terlalu kencang atau tidak berkembangnya dengan baik akibat kurangnya arus yang muncul.

\section{Stasiun $\mathrm{V}$}

Nilai skor hasil evaluasi parameter fisika, kimia dan biologi untuk stasiun $\mathrm{V}$ menunjukkan kriteria sesuai (S2) untuk lokasi budidaya rumput laut $E$. cottonii (Tabel 1). Stasiun V masuk dalam kriteria sesuai karena semua komponenn primer yang ada berada dalam kategori baik, begitupun dengan komponen sekunder dan tersier.

\section{KESIMPULAN DAN SARAN}

Berdasarkan hasil penelitian maka dapat disimpulkan bahwa hasil identifikasi parameter físika, kimia dan biologi di perairan Selayar, menunjukkan nilai yang berbeda pada setiap stasiun. Hasil analisis kesesuaian perairan bagi pengembangan budidaya rumput laut di perairan zona pemanfaatan pulau Selayar berada pada kategori cukup sesuai (Stasiun 1-4) dan sesuai (Stasiun 1). Zona budidaya rumput laut dapat dilakukan di kelima stasiun atau di desa Bonelohe, Baruyya, Barugayya, Dodaia dan Tongketongke.

Saran dalam penelitian ini adalah perlu dilakukan penelitian lebih lanjut untuk memperoleh data dan informasi yang mendukung kegiatan budidaya E. cottonii yang berada pada musim yang berbeda.

\section{DAFTAR PUSTAKA}

APHA, AWWA, WPCF. 1989. Standar Methods. For The Examination of Waterand Waste Water. Clesceri, L. S.,. Greenberg, A. E. Trussel, R.R. (ed). 17th Edition, Washington D.C.
Bakosurtanal. 1996. Pengembangan Prototipe Wilayah Pesisir dan Marin Kuppang-Nusa Tenggara Timur. Pusat Bina Aplikasi Inderaja dan Sistem informasi Geografis, Cibinong.

Basmi. J. 2000. Planktonologi :Plankton Sebagai Bioindikator Kualitas Perairan. Makalah, Fakultas Perikanan Institut Pertanian Bogor,Bogor.

Brotowijoyo, M.D., Tribawono, Dj., Mulbyantoro, E. 1995. Pengantar Lingkungan Perairan dan Budidaya Air. Penerbit Liberty, Yogyakarta.

Coremap. 2006. Pelatihan Budidaya Laut Benteng, 29-31 Agustus 2006. Yayasan Mattirotasi. Makassar.

\section{Departemen Kelautan dan Perikanan. 2002. Modul Sosialisasi dan Orientasi Penataan Ruang, Laut, Pesisir dan Pulau-Pulau Kecil. Ditjen Pesisir dan Pulau-Pulau Kecil. Direktorat Tata Ruang Laut, Pesisir dan Pulau-Pulau Kecil, Jakarta.}

Effendi, H. 2003. Telaah Kualitas Air Bagi Pengolahan Sumberdaya Hayati Lingkungan Perairan. Kanisius. Yogyakarta.

Hutabarat, S. 2000. Peranan Kondisi Oceanografi terhadap Perubahan Iklim, Produktivitas dan Distribusi Biota Laut. UNDIP, Semarang.

Lobban, C.S., Harrison, P.J. 1997. Seaweed Ecology and Physiology. Cambridge University Press. Cambridge.

Nasution,S.2001. Metode Research (Penelitian IImiah). Penerbit Bumi Aksara, Jakarta. 
Nontji, A. 2005. Laut Nusantara. Edisi revisi. Penerbit Djambatan, Jakarta.

Rasyid. A.J. 2005. Studi Kondisi Fisika Oseanografi Untuk Kesesuaian Budidaya Rumput Laut Di Perairan Pantai Sinjai Timur. Jurnal Torani $15: 73-80$.

Suin, N. M. 1999. Metode Ekologi. Dirjen Pendidikan Tinggi. DepartemenPendidikan dan Kebudayaan. Jakarta.

Supriharyono. 2000. Pelestarian dan Pengelolaan Sumberdaya Alam di Wilayah Pesisir Tropis. Penerbit PT. Gramedia Pustaka Utama, Jakarta.

Yususf. S. A.,. Wouthuyzen, S., Lusykooy, P.H. 1995. Plankton dan Kesuburan Perairan di Wilayah Pesisir Kupang dan Sekitarnya. Status Ekosistem Wilayah Peisisr Kupang dan Sekitarnya. Woutthuyzen, S. (ed). Pusat Penelitian dan Pengembangan Oceanologi. LIPI, Ambon. 